\title{
Birger Andersen
}

Dekan for det Erhvervssproglige Fakultet, Handelshøjskolen i Århus

\section{Forskningspolitik på handelshøjskoler og universiteter}

Da redaktionen af HERMES bad mig skrive et indlæg om mit syn på forskningspolitik på handelshøjskolernes og universiteternes humanistiske fakulteter, var det med stor fornøjelse, jeg tog udfordringen op, dels fordi der efter min opfattelse generelt hersker en alt for rungende tavshed om emnet, dels fordi det kunne bidrage til at rydde nogle misforståelser af vejen vedr. forskningsmæssige ressourcetildelinger til hhv. universiteternes og handelshøjskolernes humanistiske fakulteter.

Jeg skal straks understrege, at mit indlæg ikke skal ses som et bidrag til den debat, som bl.a. Hans-Peder Kromann har lagt op til i tidligere numre af HERMES. Mit primære ærinde er ikke at blande mig i diskussionen om, hvorvidt det er muligt at afgrænse et specifikt erhvervs- eller fagsprogligt forskningsfelt og på den baggrund fastlægge "naturlige" forskningsopgaver for handelshøjskolernes erhvervssproglige fakulteter. Skulle det ske, at jeg forledes til at antyde holdninger til det spørgsmål, er det altså kun som udløbere af en diskussion af, hvorvidt i første række de erhvervssproglige fakulteter har en forskningspolitik, og hvori den i givet fald består.

Lad det være mig tilladt fra starten at stille nogle tilsyneladende ganske naive spørgsmål: Hvem er det, der bestemmer, hvad der skal forskes i på de højere læreanstalter? Hvem er det, der styrer disse institutioners forskningspolitik i de tilfælde, hvor man kan tale om en sådan? Og hvad skal man i det hele taget forstå ved begrebet "forskningspolitik"?

Det har altid været og bør altid være et fundamentalt princip for forskningen i Danmark, at den enkelte forsker nyder frihed med hensyn til valg af sit forskningsområde og sine forskningsmetoder. Det er det frie metodevalg, der er med til at sikre ny erkendelse og indsigt, og i hvert fald hvad angår grundforskningen, er det næppe for meget at hævde, at forskningsfrihed er en fundamental betingelse for forskning overhovedet.

I dette perspektiv kunne det se ud som om begrebet forskningspolitik, forstået som en overordnet styring af det enkelte instituts eller den enkelte institutions forskning, ikke giver nogen mening. På den anden side er det klart, at den enkelte forsker ikke driver sin forskning i et tomrum, 
men er underkastet nogle institutionelle rammer, der afgrænser hans/hendes forskningsområde.

For det første lægger det enkelte institut, som forskningen udøves inden for, nogle naturlige rammer for den enkelte forskers forskningsområde, og for det andet lægger stillingsopslag i reglen yderligere begrænsninger på den enkelte forskers valg af forskningsområde.

Disse begrænsninger i den enkelte forskers forskningsfrihed er der sjældent, om nogensinde, sat spørgsmålstegn ved; tværtimod oplever den enkelte institution det som positivt, at der med baggrund i den forskning, der drives eller $\emptyset$ nskes drevet ved det enkelte institut, kan opstilles en forskningsprofil for et fakultet eller institution som helhed.

Da Direktoratet for de Videregående Uddannelser (DVU) i 1986 bad de enkelte institutioner om at formulere en langsigtet faglig planlægning for forskningen var det med stor begejstring - men også med de obligatoriske forbehold vedr. forskningsfriheden - vi gav os i kast med opgaven på Det erhvervssproglige Fakultet ved Handelshøjskolen i Århus. Resultatet — et værk på 40 sider — er ikke blot et udtryk for Fakultetets egen opfattelse af sin forskningsprofil, men også for ønsker for fremtiden, altså en egentlig forskningspolitik.

Når der høres kritiske røster vedr. begrebet forskningspolitik, er det altså ikke den på institutions- eller fakultetsniveau formulerede politik, der er i søgelyset. Skytset er derimod rettet mod forskningspolitiske tiltag ovenfra, enten fra DVU eller fra forskningsrådene, der gennem ændringer i tildeling af forskningsressourcer til de enkelte institutioner fors $\emptyset$ ger at op- eller nedprioritere forskellige forskningsområder. Lad mig nævne nogle eksempler, der har berørt Det erhvervssproglige Fakultet ved Handelshøjskolen i Århus:

I 1988 bevilgede Folketinget et beløb på 70 millioner kr. til styrkelse af grundforskningen ved universiteter og højere læreanstalter. Som et resultat af, at særlige områder, herunder den erhvervssproglige forskning, blev fundet værdige til opprioritering, foretog DVU en skævdeling af bevillingen, som kom de erhvervssproglige fakulteter til gode. Sideløbende har DVU i en årrække "lagt penge til side" til en såkaldt humanioraomstillingspulje, som i dag finansierer en række stillinger ved de erhvervssproglige fakulteter.

Også Statens Humanistiske Forskningsråd (SHF) har indset, at den erhvervssproglige forskning mangler et løft. I 1987 iværksatte SHF således et femårigt initiativ vedr. "Fagsprog og fagsproglig kommunikation i erhvervslivet" i den erkendelse, at situationen inden for initiativets område er præget af et betydeligt forsknings- og vidensefterslæb i Danmark. 
Af SHF's begrænsede midler blev der afsat næsten 6 millioner kr. til formålet. Senest har SHF som en udløber af sit satsningsområde "Fagsproglig forskning" udbudt et projekt med titlen "Oversættelse af fagsprog" i licitation blandt interesserede projektgrupper. Projektet er ikke begrænset til grupper bestående af forskere fra handelshøjskolerne; tværtimod lægger SHF vægt på, at der dannes projektgrupper med deltagere fra et bredt udsnit af danske højere læreanstalter. Jeg kvier mig imidlertid ikke ved at hævde, at det ville have set "unaturligt" ud, hvis en projektgruppe uden deltagelse af handelshøjskoleforskere var løbet med pengene.

Det er vanskeligt at drage andre konklusioner end den, at såvel DVU som SHF gennem disse bevillingsmæssige tiltag påtager sig rollen som forskningspolitikere. Der er tale om reallokeringer af ressourcer med henblik på opprioritering af ganske bestemte forskningsområder.

Og ude i kulissen står universiteternes humanioraforskere og skummer af raseri over, at disse forskningsmæssige parvenuer på handelshøjskolerne får både i pose og sæk.

Inden knivene drages frem, vil jeg gerne gøre opmærksom på et par kendsgerninger vedr. handelshøjskolernes forskningsmæssige bevillingssituation sammenlignet med universiteternes. I en "Budgetanalyse vedrørende de videregående uddannelser og forskningen" udarbejdet af Undervisningsministeriet og Finansministeriets Budgetdepartement i juni 1989 kan man i Bilag 9 klart aflæse, hvordan de humanistiske forskningsressourcer fordeler sig mellem universiteter og handelshøjskoler. For universiteterne udgør de forskningsmæssige ressourcetildelinger i gennemsnit $44 \%$ af den samlede ressourcetildeling. For handelshøjskoleområdet er det tilsvarende tal 19\%. I absolutte tal fik universitetsområdet i 1989 ialt 193 mill. kr. og handelshøjskoleområdet 23 mill. kr. til forskningsformål. Disse tal er dog næppe sammenlignelige, idet universiteterne jo har en langt bredere vifte af forskningsforpligtelser inden for humaniora end handelshøjskolerne, men de er med til at understrege, at handelshøjskolerne langt fra er forgyldte i forskningsmæssig henseende, og at de klatskillinger, der falder af $\mathrm{i}$ forbindelse med den overordnede omfordeling af ressourcerne slet ikke sikrer en reel ligestilling for de to hovedområder. Tværtimod mener jeg, de er med til at tilsløre den fundamentale skævhed, der består imellem dem.

Det handler imidlertid ikke om penge alt sammen. Selv om forskningens kvalitet ikke er uafhængig af den mængde ressourcer, der afsættes til at drive den for, bl.a. fordi god forskning - med enkelte undtagelser - produceres der, hvor der har været afsat midler til opbygning af forsk- 
ningsmiljøer, så er rimelige forskningsressourcer ikke i sig selv nogen garanti for, at investeringen belønnes med gode forskningsresultater.

Og der er således heller ikke nogen garanti for, at en overordnet reallokering af forskningsressourcer til handelshøjskolerne automatisk omsættes i erhvervssproglig forskning af international standard.

Forudsætningen er, at de erhvervssproglige fakulteter forstår at forvalte ressourcerne lokalt gennem en målrettet lokal forskningspolitik. Det stiller først og fremmest krav om, at disse fakulteter skaber sig en forskningsidentitet ved at gøre sig deres forskningsmæssige opgaver klart, hvilket naturligvis igen indebærer, at de stiller sig følgende spørgsmål:

(a) Er det de erhvervssproglige fakulteters hovedopgave at drive erhvervseller fagsproglig forskning?

(b) I givet fald: Kan erhvervs- eller fagsproglig forskning anskues som anvendt forskning, der bygger på den almene sprogvidenskab?

(c) Kan de erhvervssproglige fakulteter derfor tillade sig at anvende ressourcer på almen sprogvidenskabelig forskning?

Jeg mener, at svaret på alle tre spørgsmål er ja. Og jeg mener, at erfaringerne vidner om, at den tilførsel af alment baserede sprogforskere, handelshøjskolerne har fået og stadig får fra universiteternes humanistiske fakulteter bærer frugt $\mathrm{i}$ form af opbygningen af solide fagsproglige forskningsmiljøer ved de erhvervssproglige fakulteter.

Det er disse miljøer, der gennem en målrettet forskningspolitik har sat en række forskningsfelter på dagsordenen for den sprogvidenskabelige forskning som helhed, eller i det mindste i væsentlig grad styrket den samlede indsats på en række forskningsfelter. Uden at forklejne andre miljøers indsats, vil jeg hævde, at områder som terminologi, leksikografi, maskinstøttet oversættelse, datalingvistik generelt, tekstlingvistik og pragmatik, korpuslingvistik (hvad det så end er), osv. næppe ville befinde sig der, hvor de er i dag, havde det ikke været for de fagsproglige forskningsmiljøer ved handelshøjskolernes erhvervssproglige fakulteter.

Det er også, måske mere kontroversielt, min opfattelse, at disse relativt nye forskningsmiljøer i højere grad end de mere traditionsbundne universitetsmiljøer er i stand til at "flytte sig" forskningsmæssigt, afstikke de nye retningslinjer for forskningen, som er nødvendige i den periode, hvor fagsproglig forskning som et forholdsvist nyt forskningsområde skal etableres. Derfor tror jeg, at de erhvervssproglige fakulteter indtil videre vil vise sig at være den bedste grobund for de nye initiativer, som iværksættes for de "ekstra" midler, som den overordnede forskningspolitik lader flyde til os. 